\title{
Origin of modern humanity in the light of system analysis
}

\section{El origen de la humanidad moderna a la luz del análisis de sistemas}

DOI: $10.46932 / \mathrm{sfjdv} 2 \mathrm{n} 3-045$

Received in: May 1st, 2021

Accepted in: Jun 30th, 2021

\author{
Yury I. Lobanovsky \\ Ph. D., Fluid Mechanics, Thermodynamics, Auto Oscillations, System Engineering \\ IRKUT Corporation \\ 68, Leningradsky prospect, Moscow, 125315, Russia \\ E-mail: streamphlow@gmail.com
}

\begin{abstract}
This paper describes dynamic process of a small sapient group development, left Africa about $130 \mathrm{ka} \mathrm{BP}$, which led to the fact that they, having turned into modern humans - Homo sapiens sapiens, became the only human species that dominates on the Earth. It is shown how, in the course of this process, one branch of the sapiens captured an enclave in Levant from Neanderthals, and the other settled in Asia, mainly in Southeast. How, after explosion of Toba stratovolcano $72 \mathrm{ka} \mathrm{BP}$, almost all Asian sapiens died, with the exception of three small groups that survived this Catastrophe: in Khatlon valley among Pamir mountains in the north, on Timor in the south, and also Big Luzon in the east, which gave the beginning of three types of modern mankind - northern, southern and eastern. Further, the northerners and easterners (with a lag of $\sim 15 \mathrm{kyr}$ ) settled the depopulated territories in Asia, and the southerners - lands in Sahul that had never known a man before. After that, the northerners achieved victory in war in Europe, as a result of which Neanderthals disappeared forever, and survived a new, at least, all-European catastrophe - the explosion of Archiflegreo stratovolcano $39.3 \mathrm{ka} \mathrm{BP}$. Then they re-settled in depopulated lands of Europe and cold northeastern Asian territories (from which they were later driven out by newcomers from east), and in south there was a meeting of easterners with southerners on the so-called Wallace Line. A group of northerners at the same time invaded Africa, and drove out there aboriginal archaic sapiens gradually almost completely.

All elements of this process, the description of which was obtained through the use of a system analysis of available information, not only fully agree with archaeological, anthropological, paleogenetic, paleoclimatic, geological, physical and other data known to us, but also answer almost all questions about the origin and ways of modern mankind expansion and remove those contradictions and problems, which discuss in scientific community.
\end{abstract}

Keywords: archeology, anthropology, Pleistocene, catastrophe, Sapiens, Neanderthals, Toba, Archiflegreo.

\section{RESUMEN}

En este trabajo se describe el proceso dinámico de desarrollo de un pequeño grupo de sapiens, que abandonó África alrededor de $130 \mathrm{ka} \mathrm{BP}$, y que condujo a que, convertidos en humanos modernos -Homo sapiens sapiens-, se convirtieran en la única especie humana que domina la Tierra. Se muestra cómo, en el curso de este proceso, una rama del sapiens capturó un enclave en Levante de los neandertales, y la otra se asentó en Asia, principalmente en el sureste. Cómo, tras la explosión del estratovolcán Toba 72 ka BP, murieron casi todos los sapiens asiáticos, con la excepción de tres pequeños grupos que sobrevivieron a esta catástrofe: en el valle de Khatlon, entre las montañas de Pamir, en el norte, en Timor, en el sur, y también en el Gran Luzón, en el este, lo que dio lugar al inicio de tres tipos de humanidad moderna: 
norteños, sureños y orientales. Además, los norteños y orientales (con un desfase de $\sim 15$ kyr) se asentaron en los territorios despoblados de Asia, y los sureños, en tierras de Sahul que nunca habían conocido al hombre. Después, los norteños consiguieron la victoria en la guerra en Europa, como resultado de la cual los neandertales desaparecieron para siempre, y sobrevivieron a una nueva catástrofe, al menos, totalmente europea: la explosión del estratovolcán Archiflegreo 39,3 ka BP. Luego se reasentaron en tierras despobladas de Europa y en territorios fríos del noreste de Asia (de los que fueron expulsados más tarde por los recién llegados del este), y en el sur se produjo un encuentro de orientales con sureños en la llamada Línea Wallace. Un grupo de norteños invadió al mismo tiempo África, y expulsó allí a los sapiens arcaicos aborígenes gradualmente casi por completo.

Todos los elementos de este proceso, cuya descripción se obtuvo mediante el uso de un sistema de análisis de la información disponible, no sólo concuerdan plenamente con los datos arqueológicos, antropológicos, paleogenéticos, paleoclimáticos, geológicos, físicos y otros conocidos por nosotros, sino que también responden a casi todas las preguntas sobre el origen y las formas de expansión de la humanidad moderna y eliminan aquellas contradicciones y problemas, que se discuten en la comunidad científica.

Palabras clave: arqueología, antropología, Pleistoceno, catástrofe, Sapiens, Neandertales, Toba, Archiflegreo

\section{INTRODUCTION}

This article is a digest of extensive work (Lobanovsky, Yu. I., 2021, for brevity, hereinafter, this link will be denoted as L, 2021), which presents a system of evidence for adequacy of the process of origin and initial development of modern mankind described there in the period from $130 \mathrm{ka} \mathrm{BP}$ - the time of first successful exit of homo sapiens from Africa to $30 \mathrm{ka} \mathrm{BP}$ - the time when the struggle of human species for its existence was ended. By this time, instead of 5 or even, perhaps, 6 of human species who lived at the beginning of this period on the Earth, only one species remained - Homo sapiens sapiens or modern man, at that time represented by three races: proto-Europeoids, proto-Mongoloids and protoAustraloids (ancestors of Australian Aborigines, Papuans and Melanesians). This, of course, doesn't exclude the possibility that in some places in the jungle and South African deserts small groups of relict sapiens have survived, separated from the phylogenetic tree of modern humans a little earlier than escape of sapiens from Africa $130 \mathrm{ka}$ BP. People of these groups became the ancestors of modern Khoisans, equatorial pygmies and, possibly, some more marginal human groups.

Consequently, the results of the competitive struggle of all these types of man, periodically expressed in direct military clashes between them, and, according to our data, usually ended with total destruction of enemy or, at least, all of his males, look like as the results of global Eurasian war of all against all, ending in the victory of our ancestors. Therefore, a systemic consideration of all movements, expansions, arrivals, departures/leavings and deaths of sapiens in known geographical points in the period under consideration should be interpreted as episodes of this global 100-thousand-year war, using methods developed in the framework of theory of wars and military art for analysis. For the first time, as far as the 
author of this article knows, such an approach was proposed in paper (Longrich, N., 2020). In essence, the theory of wars and military art, at least in its best examples (The Art of War, 2007; Liddell Hart, B. H., 1967), is a qualitative version of system theory and system analysis application (Bertalanffy, von, L., 1969; Peregudov, F. I., Tarasenko, F. P., 1989) to one of the specific spheres of human activity.

A century and a half effort of archaeologists and anthropologists, supported in recent decades by research in the field of paleogenetics, paleoclimatology, geology and other sciences, have also made it possible to use quantitative methods for assessing Pleistocene logistics - the movements and/or migrations of our ancestors along the oecumene and the use of resources available to them. Together with their remains and artifacts, this made it possible, albeit rather schematically, but quite definitely and consistently, to describe the entire process of development of Homo sapiens in the period $130-30 \mathrm{ka} \mathrm{BP}$. As a result, after studying and analyzing the information available to the author, there were data on 80 Pleistocene sites of sapiens, as well as on another 8 points of interest to us (sites of Neanderthals and relict hominins, as well as some characteristic geographical points that didn't have accurate off-system dating). Thus, a network of 88 points was obtained with known geographic coordinates and with fairly definite times of appearance or disappearance of sapiens and other hominins there. After imposing the existing logistic, geological, paleoclimatic, physical and paleogenetic constraints on this network, a directed graph was built for these 88 points, which characterizes the processes that took place with our ancestors during $100 \mathrm{kyr}$. And the verbal description of this graph is the main content of the work (L, 2021).

In fact, it is similar to construction of Periodic Table of Chemical Elements by D. I. Mendeleev. He had an array of data describing 63 elements about which atomic weights and valences were known, though for some elements the atomic weight was determined incorrectly (Aleksenko, A., 2019). In some cases, valences were also not known all. And it was connected by Mendeleev into a certain structure that has the property of periodicity. From a systemic point of view, there is no big difference in these approaches. In both cases a rather large array of points (objects characterized by a standard set of parameters), seemingly chaotically located in a certain phase space, was organized into a logically connected structure in phase space: atomic weight - valence, or in phase space: geographic coordinates time. And if this space-time structure adequately and consistently describes the emergence and development of modern mankind, it can help anthropologists, archaeologists and paleogeneticists in their further research, just as the Periodic Table helped chemists and physicists.

It should be noted that in the following text most of the references will point to work (L, 2021), the digest of which is this article. This, of course, doesn't mean that work $(\mathrm{L}, 2021)$ is the primary source of all the information used here, on the contrary, in most cases it is only its compiler, where this knowledge from very large set of sources is presented in a rather short form. However, if we would referred here to 
the true primary sources, then it would be necessary to enter the entire list of references of work (L, 2021), which has 266 units and occupies space not much shorter than entire text of this article, and it seems to be completely impractical. Therefore, in order to find out exactly where this or that information was taken from, one should refer to work (L, 2021) and its bibliography.

The author expresses his deep gratitude to all those hundreds of people whose articles and books were included in the list of work (L, 2021). In some cases, original works are nevertheless cited here directly. But this is done only when it is necessary for coherence and full understanding of the text, or in the case when they aren't included in the bibliography of source (L, 2021).

\section{FIST STAGE OF WAR: EXPANSION OF SAPIENCE FROM LEVANT TO SUNDA}

The great ancient war began with the crossing of Bab-el-Mandeb Strait by about $130 \mathrm{ka}$ BP and landing of modern man's ancestors on the coast of Arabia. The principal point here is the ability of hominids to cross the belt of Arabian and Sahara deserts, separating the inhabited zone of Central and South Africa from Eurasia. Climatologists are well aware that with a decrease in the average temperature of the Earth, dryness of its atmosphere increases, and the deserts grow in size and rigidity of their climate increases, and with the growth of temperature, due to increase in evaporation from the surface of the World Ocean, it rains more, and the deserts recede, else disappear altogether. During the ice ages, this desert belt almost always became completely impassable for hominins, dividing and isolating inhabited regions of Africa and Eurasia, and "man's exits from Africa", as well as his "entrances" there from Asia, were physically possible only during periods of significant warming (L, 2021). 
Fig. 1 - Average temperature of the Earth's atmosphere over the last $140 \mathrm{kyr}$

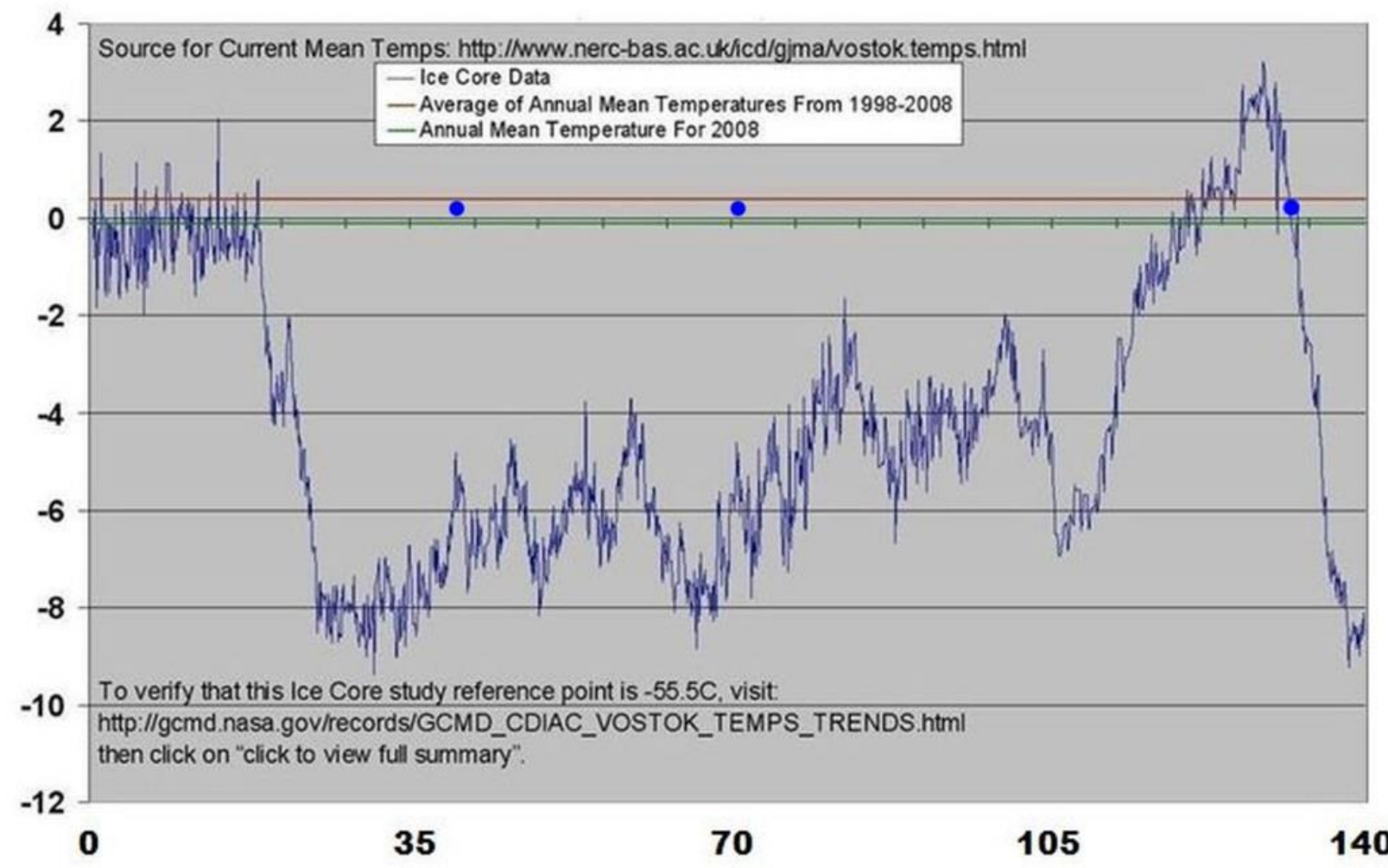

Therefore, we will consider the graph of the Earth's average global temperature for period of time of interest to us, see Fig. 1 (blue dots correspond to 130, 72 and $39.3 \mathrm{ka} \mathrm{BP}$ ). We see that between the previous $(130-115 \mathrm{ka} \mathrm{BP})$ and the current climatic optima $(\sim 15-0 \mathrm{ka} \mathrm{BP})$ the last ice age lasted, when the drop in the average temperature of the Earth's atmosphere ranged from $-3^{\circ} \mathrm{C}$ to $-9^{\circ} \mathrm{C}$. These data were built based on the studying of core drilled in Antarctic ice sheet at Vostok station. Other studies of this kind lead to even somewhat higher levels of drops to $-10^{\circ} \mathrm{C}$. Of course, some regional variations in temperature and air humidity are possible; however, paleoclimatic studies of the Arabian Desert correlate perfectly with global temperature changes. Therefore, "exits" from Africa and "entrances" there over the last million years (up to the Holocene) could occur only at certain points in time. And their number over the last $140 \mathrm{kyr}$ is no more than $3-4$ (L, 2021).

So, the window of opportunity for African sapiens has once again opened about $130 \mathrm{ka} \mathrm{BP}$. In the same time southern tip of Arabian Peninsula, located just opposite Bab-el-Mandeb Strait - Yemen is called "Happy Arabia", as its most fertile part, since moisture can be found there even in dry periods. At that time, the most advanced sapiens of Africa lived near the strait - wandering hunter-gatherers - Idaltu people who lived during the glaciation on the border of the desert. It was enough for them to overcome the strait, about $20 \mathrm{~km}$ wide, to find themselves on the earth flourishing from warming and moisture (L, 2021). 
Fig. 2 - Places of Pleistocene sites considered in the work and impact zones of catastrophic eruptions of two volcanoes against the background of Acheulean finds distribution

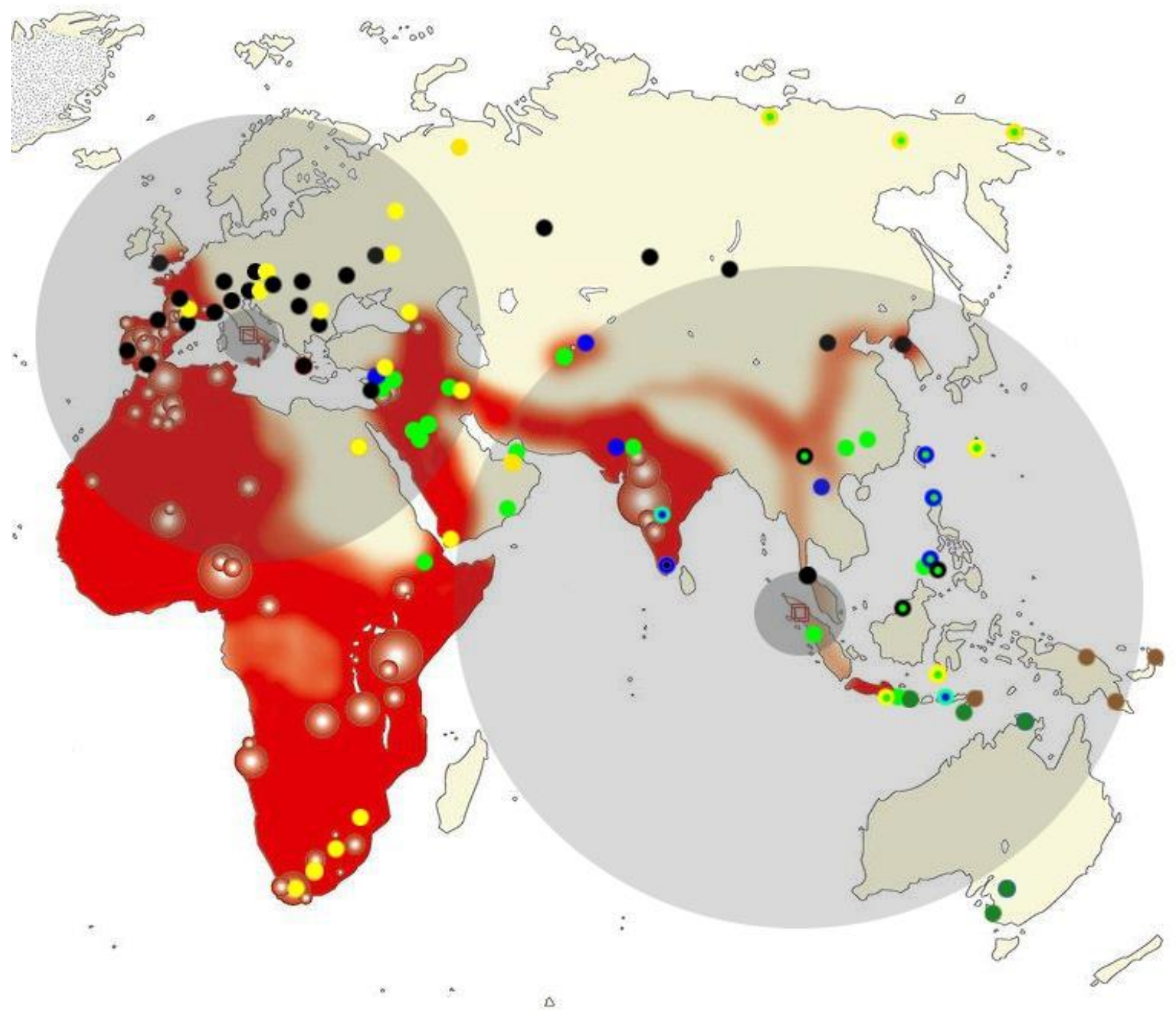

In the map above (see Fig. 2), their site is shown by a light green dot at the edge of East Africa. And all other points of light green color refer to the first period of the war we are considering, that is, to the period $130-72 \mathrm{ka}$ BP. To understand the world into which sapiens left Africa, red illumination with red and white circles of different sizes on the map shows the distribution of Acheulean stone tools (choppers, scrapers) found by archaeologists - a culture that ended just at the time sapiens left Africa. That is, we see integral traces for the period from about 1.6 million years ago to $150-120 \mathrm{ka} \mathrm{BP}$ of the distribution area of their predecessors - Homo erectus and his direct descendants, for example, Neanderthals.

Archaeological excavations in Arabia and in its environs have made it possible to find several sites of sapiens dating to $125-100 \mathrm{ka} \mathrm{BP}$. In order of movement from the strait to the exit from Arabian Peninsula they are: Dhofar, Jebel Faya (light green dots, along the coast), the vicinity of Alatar and Al Wusta paleolakes (a group of three light green dots), Humien shelter in Zagros mountains near the 
northern border of the bay at that time (the remains found there haven't been identified) and Skhul and Qafzeh caves in Levant near Mediterranean coast (also light green dots). As a result of a long war on Western Front, they were recaptured by 105 - 90 ka BP from Neanderthals living there of about $400 \mathrm{kyr}$, when the ice age began, and the desert turned out to be completely unsuitable for life. As the result, for a long time in Levant, no one managed to achieve the final victory and sapiens and Neanderthals lived there close to each other, until about $72 \mathrm{ka} \mathrm{BP}$ when sapiens disappeared without a trace. The lines connecting these points determine paths of movement of our ancestors, and the times of arrival - the speed of their movement (L, 2021).

But part of sapiens (apparently, more) at Houmian turned to the east and made a march across the south of Western Asia to India through the territories inhabited by Neanderthals. And $96-95 \mathrm{ka} \mathrm{BP}$ on eastern edge of Indian Thar desert appeared the earliest reliably dated Middle Paleolithic site in South Asia - Katoati (light green dot in northwestern India, see Fig. 2). Some of the newcomers lived there up to about $78-77 \mathrm{ka} \mathrm{BP}$, until further drying up of the desert forced them to move north, to Khatlon valley in Pamir mountains (a pair of light green and blue dots on the border of great gray circle), to the outskirts of huge Tibetan glacier, melting of which in the summer gave water for life. In the meantime, apparently, most of sapiens went east towards the warmest and most fertile region of Asia at that time - Sunda subcontinent, within which, due to a strong decrease in ocean level during the ice age, modern islands of Indonesia and bottom of modern shallow seas (located between them) turned to be solid Earth (L, 2021).

In the south of modern China, about 78 ka BP Liujiang and Fuyan caves were inhabited by sapiens (a pair of light green dots). With the same average speed of movement sapiens appeared on the (modern) island of Sumatra at the Lida Ajer site to $76-75 \mathrm{ka} \mathrm{BP}$, (a light green dot in a dark gray circle), and by the time $\sim 73 \mathrm{ka} \mathrm{BP}$ they should have appeared on seashore in extreme south of Sunda - on modern Bali island (a pair of light and dark green dots) and in its east - in Tabon caves complex on Palawan island (a pair of dots consisting of light green and blue with a light center), which was then separated from the mainland massif a strait no more than $1 \mathrm{~km}$ wide, or, possibly, was connected just a dry isthmus (L, 2021).

So, by the time the first stage of Great War ended, the sapiens had achieved significant strategic successes. They, without encountering serious resistance there, albeit loosely, settled Southeast Asia along with Sunda Land - a huge and most convenient region for human life in Eurasia in the conditions of ice age. After a fierce struggle with Neanderthals, they conquered part of Levant, creating an enclave that existed for at least $20-30 \mathrm{kyr}$. And, fleeing from the advancing desert, with the last throw they occupied another seemingly quite insignificant enclave in foothills of Pamirs, starting to adopt strategy of behavior of Neanderthals and Denisovans. It allowed this species to successfully survive near the glaciers on the 
northern edge of the oecumene for hundreds of thousands of years with all climate transitions from ice ages to interglacial optima and back (L, 2021).

\section{THE CATASTROPHE}

However, everything collapsed soon, and almost all Asian sapiens together with the majority of already few Denisovans, and, apparently, with almost all relict archanthropus, perished. It happened near 72 thousand years ago. The strongest volcanic eruption in at least 2 million years has occurred. Toba stratovolcano has exploded in the north of Sumatra, not far from the center of main region of sapiens settlement (in Fig. 2, the location of Toba is shown as a double square with red borders in the center of two gray concentric circles). The best land for life turned into a desert covered with a layer of ash, and this event completely changed course of the war. Analysis of 11 sources in which was used Toba eruption radioisotope dating, analysis of tracks from cosmic rays in volcanic glass, finds of layers of increased dust and sulfur content in ice cores of Greenland and Antarctica, and determination of separation time of Australian aborigines from the ancestral using DNA analysis, gave the date of the Catastrophe $72 \pm 2.5$ ka BP (L, 2021).

It was shown that if we exclude the nearest neighborhood of Toba with lava flows, poisonous volcanic gases and bombs, and local earthquakes, then, basically, its regional impact happened in two ways: through an air shock wave and a plume of volcanic ash carried by the wind. Approximate zones of propagation of the shock wave from the Toba explosion are shown in Fig. 2 in the form of two gray circles of different intensities. The outer boundary of the lighter circle corresponds to the estimate of the pressure drop across the shock wave of $1 \mathrm{kPa}$ (kilopascal), and the darker one corresponds to the level of $10 \mathrm{kPa}$ (atmospheric pressure is $\sim 100 \mathrm{kPa}$ ). Nominal radii of these circles are $4950 \mathrm{~km}$ and $650 \mathrm{~km}$ for explosion energy of $140 \mathrm{Gt}$ in TNT equivalent. The estimates were carried out using the Sadovsky formula, and the energy of the volcano's explosion was determined by the volume of the ejected dense rock equivalent (DRE) (L, 2021).

This highly simplified pattern in Fig. 2 however gives some representation of shock wave impact on the environment. In addition, the boundary with pressure level on the wave $1 \mathrm{kPa}$ roughly indicates the distance over which a plume of volcanic ash can stretch downwind. With the explosion of $39.3 \pm 0.1 \mathrm{ka}$ BP in Italy, Archiflegreo stratovolcano (Phlegrean fields are now in its place), westerly wind carried volcanic ash plume across Mediterranean, Balkans, Northern Black Sea region and south of modern Russia up to the Southern Urals. And just about the same distance, or even somewhat closer, passed the boundary of the $1 \mathrm{kPa}$ pressure zone on the shock wave during this event. So it is also an indicator of possible length of such a plume, which is the most formidable direct danger on the ground when volcanoes 
explode at great distances from them. At a pressure drop of $10 \mathrm{kPa}$ (the darker gray area around Toba in Fig. 2) there is the outer boundary of shock wave lesion zone for an unprotected person (L, 2021).

Due to fact that this happened in the warm season of the year, when the southern and southeastern monsoons blew there, turning northeast after crossing the equator, ash from volcano, which ended up in the troposphere, in its bulk was carried to Bay of Bengal and to India. Due to variable winds at different altitudes in the stratosphere, the volcanic cloud was "disarranged" and ash was carried into Southeast Asia and to South China Sea too, turned out it to Philippines. It is alleged that after the eruption in the south of Hindustan subcontinent, a layer of ash formed an average of $15 \mathrm{~cm}$ thick, and in some places it had a thickness of up to $6 \mathrm{~m}$. Some parts of Malaysia were covered with a layer of ash up to $9 \mathrm{~m}$ thick. In general, the ash fall zone extended from $10^{\circ}$ south to $\sim 25^{\circ}$ north latitude, and from $65^{\circ}$ to $120^{\circ}$ east longitude, and its area turned out to be about 10 million $\mathrm{km}^{2}$ (L, 2021).

Therefore, almost entire region inhabited by hominins in eastern Asia has become lifeless. Only at a distance of $2700 \mathrm{~km}$ from Toba in the directions from it to the northwest (Jwalapuram in South India - in Fig. 2 a blue dot with a dark blue center), and to the southeast (Liang Bua "hobbit" cave on Flores Island, the same designation) at two sites, at least at the first time, their population was preserved. They were created not by sapiens, but by various types of relict hominins (dwarf ones on the island), and therefore these sites, so as not to confuse it with sapiens sites, have double marking. In addition, at close to the indicated distances, there were 2 more sites in the northeast. These are Tabon caves on Palawan Island (a pair of light green and dark blue dots with a light green center at a distance of $2250 \mathrm{~km}$ from Toba) and Callao cave in the north of Luzon Island - the same dark blue point with light green center at $3020 \mathrm{~km}$ from Toba. To the southeast of Toba, about the same as in Tabon, the pressure level on the shock wave of $2.5 \mathrm{kPa}$ was reached at the southern tip of Sunda (now is island of Bali, in Fig. 2 a double lightdark green dot is put on this place) on distance of $2170 \mathrm{~km}$ from Toba. Thus, sapiens who reached these places before the Catastrophe, unlike the inhabitants of Lida Ajer cave (a light green dot next to the volcano), in principle (according to the data on impact of shock wave on a person during nuclear explosions) could survive and even, as if would, stay to live there and further (or go further to the east or north). Therefore, the forward groups of sapiens who reached these places, together with a group from Khatlon valley, became the nuclei from which modern mankind grew (L, 2021). 
Fig. 3 - Drop in Earth temperature due to Toba eruption in the second year after it

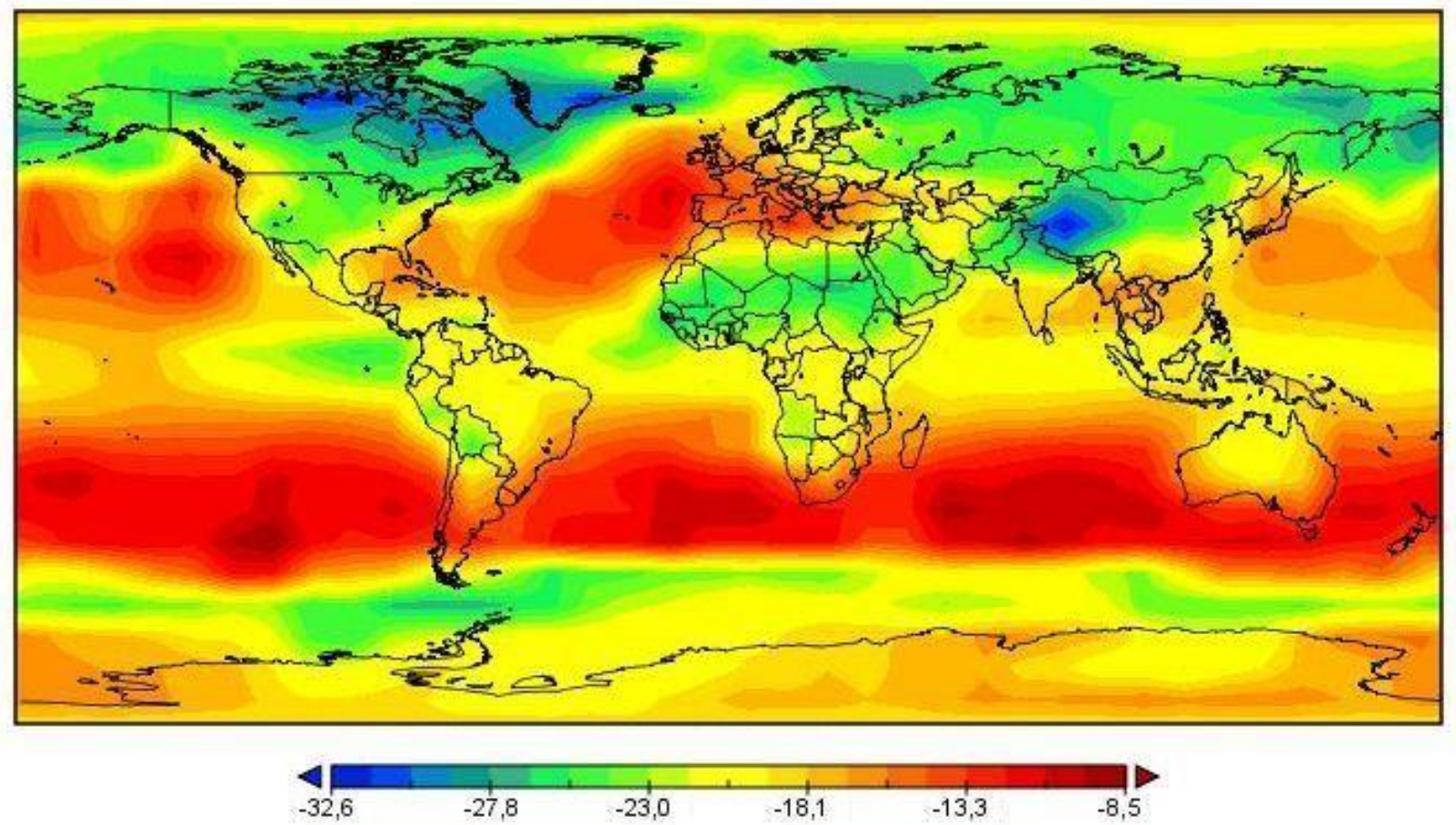

But they had to survive even and more long-term global consequences of the Catastrophe - a general drop in the Earth's temperature due to a decrease in the transparency of its atmosphere, caused by ingress of a very large amount of tiny aerosol particles into the stratosphere, that is, the so-called "volcanic winter". Earlier, a semi-empirical method was developed to determine a magnitude of the drop in the average temperature of the Earth, which was used together with open source software EdGCM to numerically calculate the climate. It has been calibrated and verified using data from temperature drops during major volcanic eruptions over the past two centuries. At present, according to the data of this method, the drop in the average temperature of the Earth's atmosphere during the explosion of Toba stratovolcano with an explosion energy of $140 \mathrm{Gt}$ (gigatons) in the TNT equivalent would be in the second year after the explosion (the most difficult) by $20.2^{\circ} \mathrm{C}$ (see Fig. 3). During the ice age, when the overall temperature of the Earth was lower and its ice caps were more, the temperature drop was $19.7^{\circ} \mathrm{C}$. Accordingly, the regional temperature drops shown in Fig. 3 would be about $2.5 \%$ lower, than shown in Fig. 3 (L, 2021).

Thus, regional cooling after Toba explosion in the second year after the Catastrophe varied from $-32^{\circ}$ to $-8^{\circ}$. Zones of maximum regional cooling are concentrated, as expected, on the continents due to large thermal inertia of the ocean. In general, zones of the most severe temperature drop occur in the central regions of large continents, and it becomes especially bad in almost all of Asia and North America due to the fact that they are washed by the open ocean mainly from the south, and the north is a continuous ice desert. But it gets very cold in the desert belt of Africa and Arabia too. Western Europe is in much 
better position, as this relatively small land mass is surrounded by water on three sides. Of course, during ice age, the picture in Europe wasn't as optimistic because of glacier lying in its north, however, oddly enough, even during the strongest Quaternary glaciation the southern boundary of floating ice in North Atlantic were near Iceland. But $72 \mathrm{ka} \mathrm{BP}$ the global temperature of the Earth was initially $4-5^{\circ} \mathrm{C}$ higher than during the most severe glaciations (L, 2021).

However, we are primarily interested in three completely other places on Asian map: Khargushon plateau in Khatlon valley in the western foothills of Pamirs and the vicinity of Timor and Luzon islands - three points on Earth where three groups of sapiens have survived, and where they became Homo sapiens sapiens. Unexpectedly, at least for us, a zone of relatively moderate cooling from Western Europe reaches almost to the foothills of Pamirs, despite the fact that near the east there is a zone of terrible cold over the Himalayas and Tibet. And such a picture is typical not only for this episode with the explosion of Toba stratovolcano, but also for any other cases we have considered with sufficiently strong cooling due to a decrease in the transparency of the atmosphere. Since the Malacca Peninsula and Great and Lesser Sunda Islands are located on our maps instead of Sunda, $72 \mathrm{ka}$ BP there should have been somewhat worse than shown on these maps in Fig. 3. However, it is clear that, nevertheless, Southeast Asia from this point of view is the best region among large territories (islands remote from the mainland, of course, are more better) in the case of volcanic winter, but, unfortunately, its inhabitants had already died before the onset of cold weather, being covered in Toba's volcanic ash like a shroud (L, 2021).

And these three really best shelters for salvation from the Catastrophe turned out to be the places we indicated. In the north, on Khargushon plateau beyond the mountain ranges, there was no impact of the shock wave, the ash plume remained far in the southeast, and the temperature drop was the lowest possible for the deep regions of the continent. Their brothers, the southern and eastern post-catastrophic sapiens, found themselves in a roughly similar situation. They were closer to the epicenter of the explosion, but the impact of a shock wave with a pressure drop of the order of $2.5 \mathrm{kPa}$ is quite tolerable. The ash plume did not touch the southerners at all, as it went almost entirely to the northwest, north and northeast. The drop in temperature was in the first year even less than that of the northerners, and in the second year was about the same, but in initially significantly warmer climate. There were no aggressive neighbors left next to them, and, in principle, only small and, apparently, rather harmless Floresian hobbits could be nearby, if they hadn't yet disappeared by that time. For the people of the east, almost everything was about the same as in the south, but due to the fact that the fallout of volcanic ash caught the territories where they were, this dramatically complicated their position (L, 2021).

Sapiens in Levant were in a much worse position during the "volcanic winter". There, the temperature descent was greater (see Fig. 3), and Neanderthals, more cold-resistant, at least due to their 
body structure, aggressive, hardened by the 30 - 35 thousand-year war with sapiens in this region, were nearby. Even if we assume that some of sapiens survived at first, and all Neanderthals of Levant died, then after a while Neanderthals from the less affected regions of Asia Minor and Balkans would have come there. And sapiens had nowhere to retreat - behind was the desert. The result, however, is well known. Soon all the caves of sapiens in Levant were occupied by Neanderthals and sapiens disappeared without a trace (L, 2021).

Thus, the unexpected intervention of an irresistible external force in the course of war of sapiens against all led to the fact that $72 \mathrm{ka} \mathrm{BP}$ almost all sapiens were died. There are only three their small enclaves left on the borders of oecumene - one near the glaciers of Central Asia, the second on the southern bank of Sunda, and the third on its eastern edge, separated by a huge impassable zone covered with volcanic ash. At the same time, a relatively short ( $2-3$ years), but very sharp and strong drop in ambient temperature occurred in the cold time of the ice age and all the forces of the post-catastrophic sapiens had to be thrown solely for survival. True, both Denisovans and relict hominins almost disappeared, but the main enemy, Neanderthals, endured the Catastrophe better than anyone else expanding their areal in Levant (L, 2021).

It follows from this that the mankind passed then through the so-called "bottleneck", that is, a period of time of a critical decrease in its numbers, leading to a reduction in its genetic diversity. And a comparison with the genomes of African great apes - chimpanzees and gorillas confirmed this. As a result, geneticists came to the conclusion that after the eruption of Toba, no more than $\sim 2$ thousand sapiens (or, even about an order of value less) remained in Eurasia; and in Africa, which was obviously less influenced by the Catastrophe (see Fig. 3) - about 10 thousand (L, 2021).

\section{SECOND STAGE OF WAR: EMERGENCE OF HOMO SAPIENS SAPIENS AND THEIR NEW EXPANSION, STRUGGLE OF NORTHERNERS WITH NEANDERTHALS IN LEVANT}

The next $~ 5$ kyr (72 - 67 ka BP) northern sapiens, apparently, spent in their cold foothills, recovering from all shocks and increasing their numbers to the maximum possible in this enclave. This follows from timing of their appearance after beginning of new expansion from Khatlon Valley (see blue dots in Fig. 2): their return to Katoati, a new arrival in Levant (Manot cave), appearance in South India (Madurai), and in Laos (Tam Pa Ling cave). And the time of exit $\sim 67 \mathrm{ka} \mathrm{BP}$ corresponds in the best way to their appearance at the indicated points at approximately the same average speeds of their movement along all routes (L, 2021).

History of southern sapiens during this period was much more eventful. This follows from the fact that about $65 \mathrm{ka}$ BP they have already ended up in Sahul, at the Majedbebe site in the north of present- 
day Australia (dark green dot in Australia in Fig. 2). To do this, they had to go from the southern tip of the Sunda (a pair of light and dark green dots) through 5 large islands from Lombok to Timor (dark green dot) and several (up to seven) smaller ones located between these large islands. True, even now the maximum width of the straits between these islands does not exceed $35 \mathrm{~km}$, but then there was at least $135 \mathrm{~km}$ from Timor to Sahul and there are rather strong flows in Timor Sea, so this water barrier was very serious. But it was also passed after a long ( $2.5 \mathrm{kyr})$ build-up of forces and competencies in Timor which was really homeland of southern mankind, having exhausted the resources of which they moved to the development of their new world - Eden for ascetics. It should be noted that when moving to the south of Australia (sites on Lake Mungo (55 ka BP) and in the Narakuta caves ( $53.5 \mathrm{ka} \mathrm{BP}$ ) - also dark green dots in Fig. 2) southerners who started their journey from Timor showed the same speed of expansion in Australia as the northerners in Asia (L, 2021).

By this time, they still differed little from each other, and the coincidence of their average speeds of movement on post-disaster lands is another proof of the adequacy of such logistic quantitative estimates. In addition, since there were no hominins in Sahul before the appearance of the southerners, and the resettlement of sapiens there took place "from scratch"; this means that the northerners moved also in their wanderings across Asia, practically without encountering any resistance from any survivors after the Catastrophe of another species of hominins. They went there along the pristine land, and this was the beginning of creation of a new world in which we still live (only on the border of Asia, in Levant, they collided again with Neanderthals, and the forward movement there immediately stopped by about 7.5 kyr). That is why the date of $72 \mathrm{ka} \mathrm{BP}$ is the most reasonable starting point for the emergence of modern mankind. Morphologically, these people practically didn't differ from their closest ancestors - the precatastrophic sapiens, but their stereotypes of behavior changed, proof of which is their entire further history.

The fate of group of sapiens, who at the time of the Catastrophe were in the extreme east of Sunda on Palawan Island in the vicinity of Tabon cave complex (a pair of light green and blue dots with a light green center in Fig. 2), was more difficult. In general, the impact of Toba volcano there was about the same as in the extreme south of Sunda, where there was another group of sapiens, whose descendants were southern humanity (the race of Australians and Papuans). But there was very important difference volcanic ash fell on Palawan, in the only of three zones where our ancestors could survive. Although amount of the ash was incomparable with what was in the sector from the northwest to northeast of Toba, the edge of the volcanic cloud that strewed ash into the South China Sea "hooked" Palawan - traces of volcanic ash were found on its shelf, which laid at that time above sea level. Therefore, sapiens began to move away from the consequences of the volcanic explosion in only possible direction - to the north, to 
Greater Luzon Island. At the same time, being in the ash fallout zone, they were clearly starving, which led to a rapid decrease in their growth in a time of about or even slightly less than 5 kyr. And this, apparently, can't be explained by the direct action of the so-called insular dwarfism. Only an apparent shortage of food resources due to volcanic ash could so quickly affect their reduction in size (L, 2021). And apparently, it was genetically entrenched in them, and therefore their descendants (Asians) still have, on average, the lowest growth among other modern races (not counting relicts men).

Under these conditions, it took them a long time to cross the strait about $65 \mathrm{~km}$ wide between Greater Palawan and Greater Luzon islands. And only to the moment when both northerners and southerners, having increased in number to at least $1-1.5$ thousand individuals and having exhausted the resource capacity of Khatlon valley and Timor Island, began their resettlement (and those and others) in general direction to the south, easterners finally reached the north of Luzon - the area where they could normally live. Then $(\sim 67 \mathrm{ka} \mathrm{BP})$ the first inhabitants of this island appeared there in Callao cave complex (a blue dot with a light green center in Fig. 2). Area of Greater Luzon, and, consequently, its resource capacity, was more than an order of magnitude higher than the corresponding indicators of Khatlon and Timor. Therefore, easterners could stay in their shelter $2-2.5$ times longer than, say, the northerners without attempting to resettle outside. Moreover, the only land road back (after crossing the strait between Luzon and Palawan) for 20 - $25 \mathrm{kyr}$ led first to the lifeless zone, and then to area where life had just begun to re-emerge. Therefore, no earlier than by $57-56 \mathrm{ka} \mathrm{BP}$ easterners could have a need for resettlement, that is, when the northerners and southerners had already occupied vast territories on their continents, and the islanders had only one way - across the sea. During this time, they were able to increase their skills and competencies in the field of navigation, and through a chain of small islands they were able to reach Taiwan (it was a peninsula at that time), from where they opened the way to Greater Asia (L, 2021).

Thus, the second stage of war $(72-47.5 \mathrm{ka} \mathrm{BP})$ included a very long undeclared armed-truce (about $15-17 \mathrm{kyr}$ ), when few hominins who survived the Catastrophe were engaged in solving their internal problems, with rare exceptions without entering into any relationships with other species, usually separated from them by vast and completely uninhabited territories. But at the beginning of this stage, the most difficult defeat of sapiens in the war falls - the complete destruction by Neanderthals of sapiens enclave in Levant immediately after the Catastrophe. The northerners, about $55 \mathrm{ka} \mathrm{BP,} \mathrm{began} \mathrm{a} \mathrm{new}$ campaign against Neanderthals in Levant, in which, by the time of 48 - $47 \mathrm{ka} \mathrm{BP}$, they finally won a complete and unconditional victory for the first time, taking revenge and avenging the killing $24-25 \mathrm{kyr}$ before of their distant ancestors. Also without a trace, like sapiens once, Neanderthals have disappeared from there forever. After that, this war will sweep across all Neanderthal lands, leaving alive none of them (L, 2021), see below. 
And southerners at that time traveled across Australia, forgetting about war with other species of man, and with a greater fervor exterminating largest species of Australian fauna defenseless before them. Easterners mastered Greater Luzon, settled on Taiwan Peninsula and began to settle in East Asia. Their first site there, known to us, - Xiaodong, will be described in the next section of the article, so long as the time of its foundation - 43.5 ka BP refers to the next stage of 100-thousand-year war (L, 2021).

\section{THIRD STAGE OF WAR: MOVEMENT TO THE NORTH AND "PLEISTOCENE BLITZKRIEG" - DEFEAT OF EUROPEAN NEANDERTHALS}

After victory in Levant, a new phase of war begins, which is convenient to single out as its third phase. This time, there is no such clear border as before, when the Catastrophe sharply and unequivocally divided first and second stages of this war, however, it was at this time that new factors appeared that qualitatively changed the situation on the last remaining, Western Front of Great War of sapiens against all.

Even at the previous stage, groups of Khatlon sapiens, to describe which, as will be seen from what follows, it is quite reasonable to apply the term "Cro-Magnons", using a new and critically important technology for the development of construction of pre-fabricated shelters and more fundamental dwellings, left caves and were able to settle in the so-called periglacial "mammoth steppe". These territories, also called tundra steppes, despite the cold climate, due to the large number of sunny days, in reality created conditions for the habitation approximately of the same number of animals as in the modern African savannah. So, Cro-Magnons, using new technologies, moved north (L, 2021).

While part of Cro-Magnons conquered the caves of Levant from Neanderthals, and other groups settled in India and again went to warm Southeast Asia, some of those who remained in the center of expansion zone felt the charm of "cold Africa" when they able to learn a construction of their warm dwellings relatively easily and quickly. Analyzing their sites in the north and east, which appeared already at the time in question, we can understand that Cro-Magnons from Pamir in the last quarter of this period began their expansion there, see the line of black dots in Fig. 2 from Kostenki on Russian Plain ( 45.5 ka BP) to Ryonggok site ( $40 \mathrm{ka} \mathrm{BP})$ in Korea. The dates of Cro-Magnons appearance at all these points of the "northern line" (Kostenki, Ust'-Ishim, Denisova cave, Tolbor, Tianyuan and Rionggok) are in good agreement with the assumption that they left Khatlon about $52.5 \mathrm{ka} \mathrm{BP}$ and equal average speed of movement were on all these directions. The southern border of northerners' settlement at this time is indicated by Tham Lang Rongrien site in Southeast Asia on the modern Isthmus of Malacca (43 ka BP, black dot in Fig. 2) - by this time, almost $30 \mathrm{kyr}$ after the Catastrophe, northerners finally entered the previously dead land. Easterners did the same, they reached the Niah cave in Borneo $40 \mathrm{ka}$ BP (black 
dot with a light center in Fig. 2), and moved towards the northerners and southerners through these territories (L, 2021).

It was begun at this time that what is commonly called Upper Paleolithic or Late Paleolithic revolution. This concept arose as a result of the fact that stone products began to be produced using new, more sophisticated technologies, and many different artifacts and cultures appeared. All this primarily took place on the border between sapiens and Neanderthals at the time when there was a short (by standards of the Pleistocene) $-4 \mathrm{kyr}$, but very effective military campaign of Cro-Magnons to capture Europe and to eliminate Neanderthals in its central and western regions. And, probably, it led to the rapid modernization of their stone weapons from the experience of previous fights. And weren't these innovations made in each of battle groups independently of others due to sufficiently large distances between them? The use of dwellings that can be quickly erected almost anywhere in a short time, or even simply assembled partly from local (poles, mammoth tusks), and partly from materials carried with themselves (skins), made it possible to create combat units of Cro-Magnons tribes, many times larger than any of the largest clans of Neanderthals, and upon meeting them quickly eliminate them with practically no loss. And the actualization of this possibility, apparently, was facilitated by memory of Cro-Magnons that until recently their ancestors were a single small tribe (L, 2021).

Thus, both material and, apparently, moral and psychological factors arose that turned the partisan war, consisting of countless sporadic clashes of hunters of individual sapient, Neanderthal, Denisovan clans, as well as clans of Asian archanthropus with each other, into an total war - war of significantly larger units of mobile, well-motivated to win Cro-Magnons, controlled by their already professional commanders, with Neanderthals remaining at the same level of warfare. In the previous war, physically stronger and more accustomed to the cold, Neanderthals had an advantage over recent immigrants from Africa - gracile sapiens, which they repeatedly proved in battles. However, against new strategy of the "Pleistocene blitzkrieg", which rolled for 4 kyr (45 - 41 ka BP) throughout Western Europe from Bulgaria to the south of Spain and Atlantic coast of Portugal, they were completely powerless (L, 2021).

Here we will not describe in detail this campaign, which began shortly after arrival of Cro-Magnon combat groups from Levant to southeastern Europe, to the vicinity of Bulgarian cave Bacho Kiro, about 44.8 ka BP, and ended in Portugal at Lapa do Picareiro about $40.8 \mathrm{ka}$ BP. This description can be seen in work (L, 2021). Standard "logistic" method was used to analyze this campaign. Despite the decrease in the importance of caves in the conduct of hostilities at this time, they still remained strongholds that ensure the stability of position, like, say, feudal castles in the Middle Ages. In addition, human remains and artifacts are better preserved in caves. And the last - the caves by their very existence indicate the places of possible purposeful excavations, and the ancient sites in open spaces, as a rule, are found by chance, 
Fig. 4 - Western European sites during war of Cro-Magnons and Neanderthals

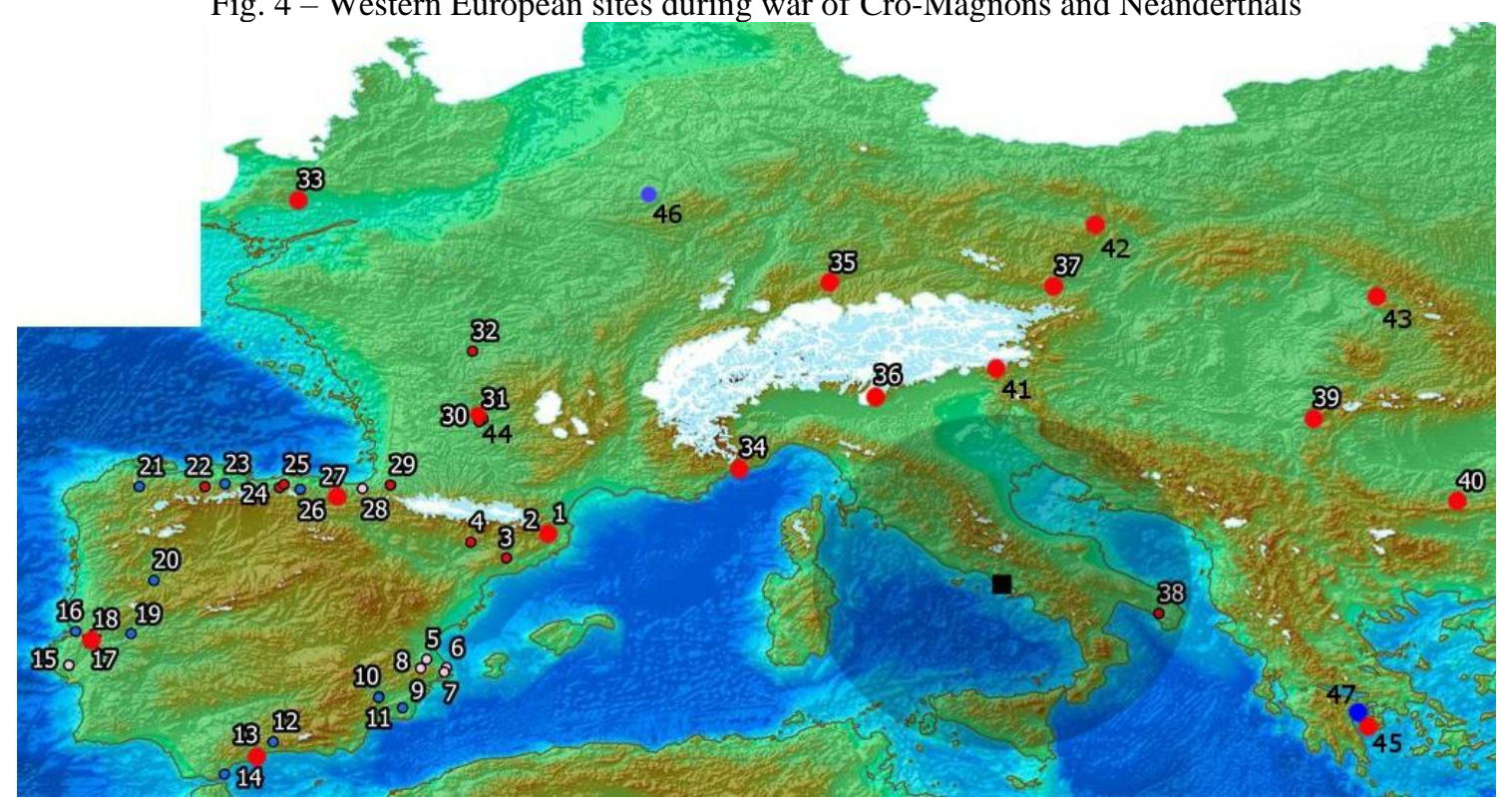

Map shown in Fig. 4 was obtained by superimposing on the original substrate from article (Haws, J. A. et al., 2020), representing a collection of heterogeneous and different-time sites of both sapiens and Neanderthals, a selected set of sites from the time of European War in form of 16 large red dots (CroMagnons) and 2 blue (Neanderthals, Goyet and Klissoura). After that, taking into account the time of appearance of Cro-Magnons at these sites, instead of the indefinite cloud of heterogeneous points the paths clearly arise along which sapiens military detachments walked across Europe in the period $45-41$ ka BP.

When analyzing the campaign, geographical coordinates and dates of 18 European archeological sites were considered. Their list is as follows: Bacho Kiro (Bulgaria, 40), Peştera cu Oase (Romania, 39), Divje Baba (Slovenia, 41), Riparo Mochi (Italy, 34), Arbreda (Spain, 1), Bajondillo (Spain, 13), Lapa do Picareiro (Portugal, 17), Willendorf (Austria, 37), Geissenklösterle (Germany, 35), La Ferrassie (France, 44), Goyet (Belgium, 46), Kent (England, 33), Korolevo (Ukraine, 43), Pod Hradem (Czech Republic, 42), Vis' (Ukraine), Kostenki (Russia), Franchthi (Greece, 45), Klissoura (Greece, 47), see the scattering of black and yellow dots in Europe in Fig. 2 (L, 2021). Of these, all 15 sites in Western and Central Europe are caves, and in Eastern Europe, all 3 sites (Korolevo, Vis' and Kostenki) were more technologically advanced and located in open places. Numbers in the list of sites after name of modern country of their 
location mean the number of point in Fig. 4. Yellow dots paired with black in Fig. 2 mean that life on these sites was interrupted during the European catastrophe (see section 5), but then were being resumed there again.

From the analysis of all available information relating to this European campaign and later periods of time, it should be concluded that it was jointly carried out by 2 Cro-Magnon "races" (in terminology of famous soviet anthropologist G. F. Debets), which, of course, should not be equated with modern human races - they only characterize some morphological and, apparently, behavioral features of two groups of immigrants from Khatlon Valley, who left it at the beginning of the primary settlement about $67 \mathrm{ka}$ BP and $\sim 10 \mathrm{kyr}$ later. The first population was later called Grimaldians. Apparently, they bore the brunt of the last war with Neanderthals in Levant, having debugged their war machine that then swept away European Neanderthals, although, of course, they became a separate population not in Italian caves of Grimaldi (or Riparo Mochi), but in $24-25$ kyr before that, having gone from Khatlon to the west. The second got its name from Debets as Brno-Předmosti "race", although Předmosti (37 ka BP) - the wellknown site in Moravia arose almost $20 \mathrm{kyr}$ after this population left Khatlon. Because of this, as in the work (L, 2021), we will call them simply "Brünners" by modern geographic landmarks. They supported "Grimaldians" in their war in Levant, closing "Neanderthal issue" there, and soon after that they moved with them to the northwest, to Europe. Well, and "Cro-Magnons proper race" according to Debets is the population that emerged from Khatlon last among all of them into the mammoth steppe on the northern border of oecumene (a series of black dots in Fig. 2, described at the beginning of this section), and, besides everything else, they were who founded the "capital of Pleistocene Europe" - Kostenki (see section 5) (L, 2021).

Southwest route of Grimaldians from the south of Alps: Bacho Kiro (40) $\rightarrow$ Peştera cu Oase (39) $\rightarrow$ Divje Baba (41) $\rightarrow$ Riparo Mochi or Grimaldi caves (34) $\rightarrow$ Arbreda (1) and further Bajondillo (14) and Lapa do Picareiro (17). Northwest route: Bacho Kiro (40) $\rightarrow$ Peştera cu Oase (39) $\rightarrow$ Willendorf (37) $\rightarrow$ Geissenklösterle (35), and therein was a split into two directions, to the south: Geissenklösterle (35) $\rightarrow$ La Ferrassie (30) $\rightarrow$ Labeco Coba (27) $\rightarrow$ Lapa do Picareiro (17), and to the north of Western Europe to Scandinavian Glacier: Geissenklösterle (35) $\rightarrow$ Goyet (46) $\rightarrow$ Kent (33). Which "race", Grimaldians or Brünners, or they together, made this northwest rout - it is now unclear. Brünners went to the north, but Carpathians forced them to deviate to the west: Bacho Kiro (40) $\rightarrow$ Korolevo (43) $\rightarrow$ Pod Hradem (42) and to the east: Bacho Kiro (40) $\rightarrow$ Vis' $\rightarrow$ Kostenki (the last 2 sites are located outside the borders of Fig. 4), where they have met with their brothers - "Cro-Magnons proper", who came directly from Khatlon. 
After that, almost all of Europe became Cro-Magnon Land, with two small exceptions: Greece and, apparently, Crimea. Campaign from Bacho Kiro to the southwest to Greece led to the emergence of only one known site of sapiens - Franchthi (45) in future Argolis, while Klissura cave (47), inhabited by Neanderthals, remained $40 \mathrm{~km}$ northwest of it, as if even blocking Franchthi. This completely unusual situation for European Pleistocene war, apparently, lasted at least $3-3.5 \mathrm{kyr}$, until everyone who lived in Greece died under ash of Archiflegreo volcano eruption, shown in Fig. 4 by a black square (see section 5) (L, 2021).

Meanwhile, southerners, at least part of them, after thinning out the fauna of Australia had to overcome their horror of volcanoes (see (L, 2021)) and go north to New Guinea, connected by a land bridge with Australia, and to nearby islands. The coming hunger turned out to be stronger than the old fear. Sites of southerners appeared in New Ireland ( 43.7 ka BP), naturally, a little earlier on the way there - in New Guinea ( 45.5 ka BP). Much later, sites arose on high plateaus of New Guinea (35 ka $\mathrm{BP}$ ), where 26 - $27 \mathrm{kyr}$ later, independently of large northern world, agriculture arose. And there was even a return to his small homeland - to the island of Timor, about $42.7 \mathrm{ka} \mathrm{BP}$. All these points are shown in Fig. 2 from right to left with four brown dots, three of which essentially form the line of maximum southerners' advancement to the north (L, 2021).

Easterners began in this time to settle in Greater Asia (just as the northerners from Khatlon began to do that $15 \mathrm{kyr}$ before), carrying with them Changbin culture from Basian site in Taiwan (a blue dot with a light green center in Fig. 2), on the mainland called Hoa Binh culture. First dated site in Greater Asia is Xiaodong (43.5 ka BP) in southern China, already a black dot with a light green center in Fig. 2 (L, 2021). Thus, while the war of Cro-Magnons against homeland of Neanderthals was unfolding in Europe, easterners, who had lagged behind the northerners and southerners in settling on the planet, began to gradually catch up and oust their competitors.

\section{FOURTH STAGE OF WAR: EUROPEAN CATASTROPHE, STRUGGLE FOR LIFE AND INVASION OF AFRICA}

So, by the time of $40 \mathrm{ka} \mathrm{BP}$, Homo sapiens sapiens took a monopoly position in Eurasia and Sahul. Its southern subspecies settled throughout Australia (with the exception of lifeless arid territories), in New Guinea and Tasmania, as well as on nearby islands, including again at the point from where it began to settle - on Timor. The northern subspecies of modern humanity - Cro-Magnons returned again to Southeast Asia, to a zone that was free of hominins almost $25 \mathrm{kyr}$. In the north and east, the Cro-Magnons advanced up to the edge of the glaciers and successfully colonized the periglacial mammoth steppe. In the south, Hindustan peninsula was inhabited, and in the west, northerners had just completely and 
unconditionally defeated their eternal and most dangerous rivals - Neanderthals, after which they disappeared from Europe, with the exception of minor enclaves in Greece. In addition, by that time, Neanderthals were still preserved west of desert Iranian Highlands in Zagros Mountains, and also, probably, in the Crimea. Easterners actively inhabited East and Southeast Asia (see (L, 2021)).

So, $32 \mathrm{kyr}$ after the Catastrophe, which brought the species Homo sapiens to brink of survival, the moment of its triumph came. But at this point, about $39.3 \mathrm{ka} \mathrm{BP}$, a new catastrophe occurred - this time Archiflegreo stratovolcano, located in the vicinity of modern Naples, exploded, almost in the very centre of European territory accessible for settlement that was just conquered by Cro-Magnons. Estimation of energy of this eruption by the volume of the ejected dense rock gives a value of about $25 \mathrm{Gt}$ in TNT equivalent, which is 5.6 times less than in the explosion of Toba stratovolcano. Therefore, in a first approximation, the same effects from explosion of Campanian stratovolcano manifested themselves at distances 1.75 times smaller than during the explosion of Toba, and area on which they exerted their influence was approximately 3 times less. So this new catastrophe, while preserving to some extent a worldwide character, was, nevertheless, in the first place, mainly pan-European. And new homeland, just conquered in course of difficult and risky campaign, suddenly turned to the victors with its unexpected face, reviving memories of the terrible past in the new inhabitants of Europe (L, 2021).

Let's draw again on the map two circles with boundaries, where the pressure drop on the shock wave was 1 and $10 \mathrm{kPa}$ - their radii were about 3250 and $405 \mathrm{~km}$. Both are shown in Fig. 2, and in Fig. 4 - only the smaller of them, since the boundaries of the larger go beyond the area shown in this figure. Within a radius of $100 \mathrm{~km}$ from the eruption epicenter, all flesh died from pyroclastic flows. Of CroMagnon sites known to us, two that of were located near the volcano at approximately the same distance - $590 \mathrm{~km}$ from the epicenter of the explosion (Divje Baba (point 41 in Fig. 4) and Fumane (point 36)), and the pressure on the shock wave there in the open area there would be about $7.5 \mathrm{kPa}(\mathrm{L}, 2021)$.

Although the impact of shock wave in mountains depends very much on local topography, nevertheless, an approximate idea of what can happen in such conditions can be gleaned from the description of destruction in abandoned village Lagerny of Russian hunters, located at a distance of 53.5 km from explosion's epicenter of the thermonuclear warhead AN602 - Tsar-bomb with an energy of 58 Mt, where the nominal pressure level on the shock wave was exactly the same. Briefly, we can say that people did the right thing by leaving this village forever shortly before the trials. Cro-Magnon hunters also left their Divje Baba cave, returning there after a break of hundreds or thousands of years. Regarding Fumane cave, we have no definite data, but there should have been the same, especially since the gorge in which this cave is located open to the south, approximately in the direction of the volcano. Their Arbreda site in Spain (point 1 in Fig. 4), which lay at a distance of 960 km, was abandoned by its 
inhabitants at a pressure level on a wave of about $3.9 \mathrm{kPa}$. But wave pressure level of $2.5 \mathrm{kPa}$, as it was already written here earlier, did not make people leave this place (Labeko Koba site, point 27, distance $1400 \mathrm{~km})(\mathrm{L}, 2021)$.

The global consequence of Archiflegreo explosion was the arrival of a new "volcanic winter". However, due to the fact that the explosion energy of this volcano turned out to be about 5.6 times less than that of Toba, the largest drop in the average temperature of the Earth's atmosphere at the moment of maximum cooling was $\sim 3$ times lower than at that time and in the second year it was $6.8^{\circ} \mathrm{C}$. In general, it is clear that a drop in temperature for several years in Europe by $3-5^{\circ}$ due to the darkening of the atmosphere, of course, is a significant nuisance for our persistent ancestors, but this circumstance could hardly put them on the brink of catastrophe. Much worse was the other. The decisive influence on lives and fates of people who had settled by this time in large areas of Europe was, as expected, volcanic ash that fell on the ground. The wind during the eruption blew in such a way that the Balkans, Ukraine and the south of East European Plain became a somewhat smaller scale analogue of Southeast Asia after the explosion of Toba, see Fig. 5. Bacho Kiro cave, Peştera cu Oase, as well as Franchthi (black dots within the red zone in Fig. 5) and Neanderthal Klissura (blue dot), all were covered with the ash of stratovolcano (L, 2021). 
Fig. 5 - Ash trail after explosion of Archiflegreo volcano and some important sites

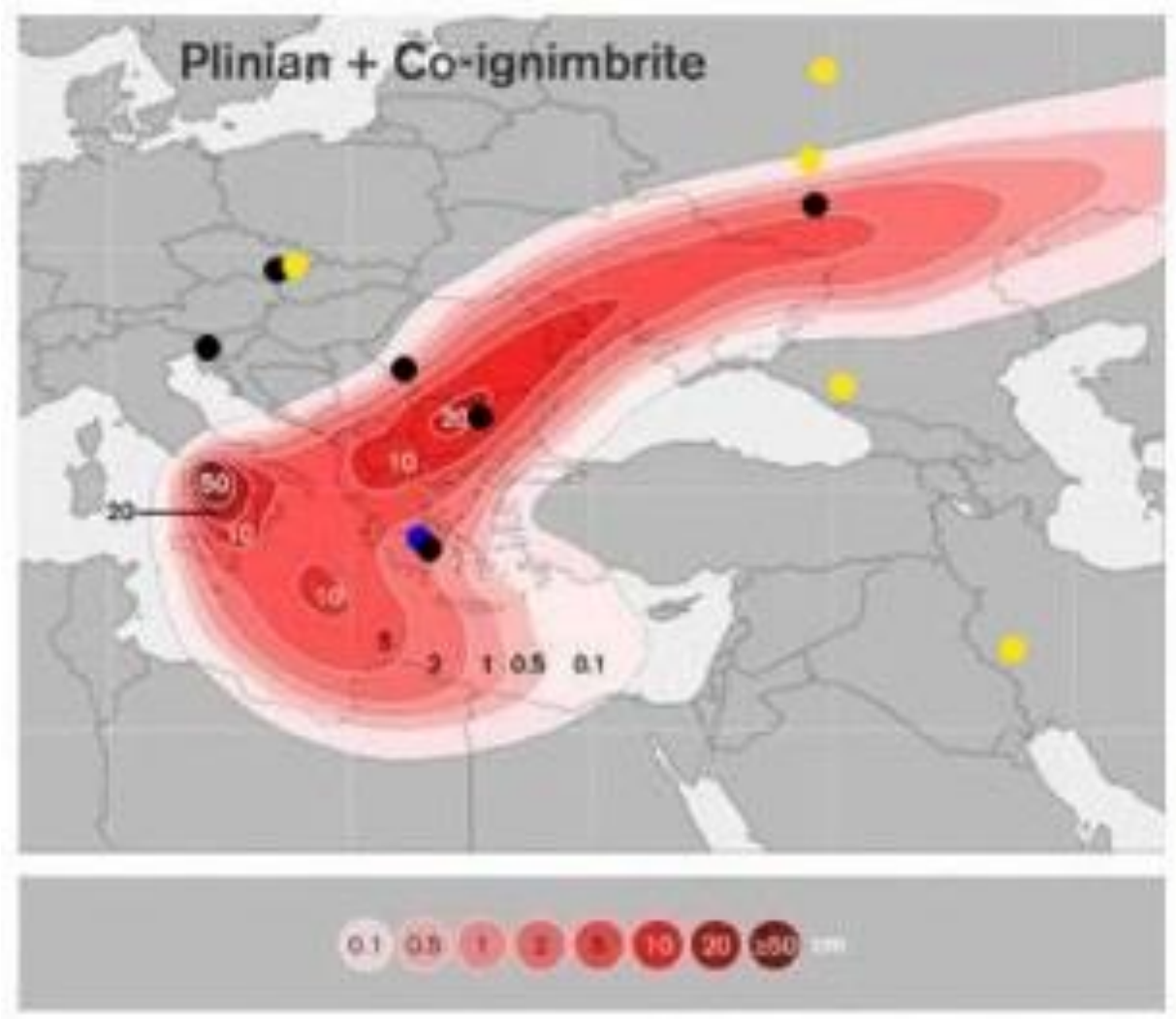

A calculated variant of volcanic ash distribution during a two-stage eruption of Archiflegreo, firstly in the form of a stable so-called Plinian phase, and secondly unstable explosive co-ignimbrite phase, is shown in Fig. 5. Volcanic ash flew to the southern Urals, covering, in addition, Cro-Magnon sites in Balkans, northern Black Sea region and famous Kostenki (the easternmost black dot in Fig. 5). Crimea, especially its south, where there were Neanderthal caves, seemed to have practically escaped ash fall. Such shape of the trail is caused by north-westerly wind, which was blown in the troposphere during the eruption, and westerly wind in the stratosphere. It follows from this that the eruption of Archiflegreo occurred not earlier than the end of September and not later than the end of March, when there were frosts in periglacial Europe (L, 2021).

Maximum width of the "stratospheric" part of the ash trail is about $550-600 \mathrm{~km}$. Kostenki site is located within ash trail at a distance of at least $150 \mathrm{~km}$ from its northern border. The total area of the ash trail from the eruption of the Archiflegreo volcano was about 3 million $\mathrm{km}^{2}$, and that part of its "stratospheric" trail, laying on the south of mammoth steppe of East European Plain, occupied an area of about 800 thousand $\mathrm{km}^{2}$, endangering life of no less than $12-15$ thousand mammoths. As the ash fell on the ground in the cold season, it covered high (up to 2 meters) dry grass ("standing hay"), consisting mainly of cereals, and shrubs growing in places. It seems that for mammoths and large ungulates caught within the ash trail this didn't immediately become a threat putting them on the brink of starvation. The 
"standing hay" did not perish, but survived to one degree or another. Ash, the layer thickness of which on average did not exceed $1-5 \mathrm{~cm}$, could be shaken off the tall dry grass. So at first, ruminants could somehow feed. Moreover, with their mobility, they could quickly migrate from the affected area (L, 2021).

However, it immediately became very bad with drinking - it was absolutely impossible to separate snow from ash, all sorts of small lakes or springs, if they at all could be found under ash in the dry steppe in winter, were also heavily polluted. There were large rivers only - if you break through the ice covering them (it was not too difficult at rapid flow), then the sufficiently clean water flowing under it could be drunk. And everyone who hasn't yet lost the ability to stand on own feet from dehydration, in search of salvation, had to go to the rivers, and then, moving along their banks, try to get out of death zone. Then Don River, apparently, was a much larger than it is now, and it crossed this zone almost exactly in the middle. Of the large rivers, its eastern quarter was crossed by Volga, and the western - by Dnieper and Desna. Thus, a noticeable part of mammoths and ungulates in trouble should have reached Don. Many of them, exhausted, could die on its banks, especially in the vicinity of the northern border of the ash zone, when the last forces left the animals (L, 2021).

Indeed, the excavations carried out over the past century and a half in this zone have made it possible to find a large number of easily identifiable mammoth bones on Don (especially, near Kostenki and higher along this river, for example, near Gagarino site, which turned out to be just on the northern border of this zone - yellow point in Fig. 5). Some estimates have shown that the share of those who died from exhaustion, as well as killed mammoths, available to the inhabitants of Kostenki complex of Paleolithic settlements, was no less than 300 - 400 heads. Together with the meat of also dead ungulates and a decoction of dry grass, this could be enough for $1-1.5$ thousand people for about 10 years. Volcanic winter and permafrost helped preserve it. At the end of the term, one could eat the brain extracted from large bones (L, 2021).

Thus, in Europe, 1 - 2 years after the eruption, a paradoxical situation developed - due to summer colds because of "volcanic winter", the grass didn't grow for several years, and ungulates and mammoths were forced to leave these places in the southwest and the east directions (the ash trail prevented them from going south through Balkans and Asia Minor). And in Central Europe there turned to be no one to hunt. The people had to follow the herds east along the northern edge of the ash trail (and those who lived to the west moved southwest). When the swift ungulates broke away from the hunters pursuing them, there was no food left outside ash trail, but inside - it was. Therefore, people from Central Europe, in search of food, had to enter the ash zone from the north along the banks of large rivers - Dnieper, Desna, Don, and do what the people who were there all this time were doing. Apparently, it was then that Kostenki became the "center of the world" (as the American archaeologist John Hoffecker said, who saw with his 
own eyes a settlement that was absolutely impossible for Paleolithic), and mixing point of the abovementioned so-called "races" of Cro-Magnons (L, 2021).

Indeed, in Kostenki there was a temporary union of three Cro-Magnon races (local "Cro-Magnon proper", Brünners from Moravia and Grimaldians from Divje Baba and the surrounding areas, who made "death marches" to the Middle Don within a few months), and this settlement itself became "the Paleolithic capital of Europe", that is, absolutely impossible in scale "a complex of spatially related archaeological objects". More than 60 hunter-gatherer sites on an area of $30 \mathrm{~km}^{2}$, this is not only unprecedented, but also simply impossible for Pleistocene. Even if only one genus lived on the site, for a stable full-fledged existence it needed lands with an area of about $500 \mathrm{~km}^{2}$. So the total need for Kostenki is more than 30 thousand $\mathrm{km}^{2}$ of hunting territories, which is 1.5 times larger than, for example, the area of Peloponnese peninsula, on which there were the states of Argolis, Arcadia, Achaea, Corinthia, Laconia, Messenia, Elis and something else smaller. On the other hand, this is only 1.5 times less than the area of entire Moscow district. Taking into account the fact that the territories beyond Don are inaccessible, the characteristic size of such an area is at least $250 \mathrm{~km}$, which is completely incommensurate with the capabilities of foot hunters. And such a settlement cannot sustainably exist for any length of time - all this was possible only for several years during the crisis we are describing, when literally mountains of meat lay nearby (L, 2021).

When peak of this "volcanic winter" passed, and in the summer grasses began to grow again, at least some of the ungulates returned to their usual places. And in the ash zone, food began to run out, and it was time for people to leave the places where life wouldn't reappear soon. And then 2 different fateful decisions were made: Eastern "proper" Cro-Magnons and Brünners, close to each other, went along Don to the north to near and already well-known border of ash trail, and the southern "race" of Grimaldians, which formed off the shores of Mediterranean Sea, and, apparently, more than others tired of the cold "volcanic winter" at the height of ice age, moved along the river bank to the south, towards the warmth. Brünners (apparently, not only from Kostenki, but also from somewhere else, for example, from Dnieper and Desna), returned to Moravia, and already, relying on Don, or rather, Siberian technologies for construction of dwellings began to establish their own settlements on ground, such as Předmosti (yellow dot in the center of Europe in Fig. 2 and similar yellow dot in Fig. 5). And the eastern "proper" CroMagnons went north to glacier, creating Sungir site (yellow dot to the north of Kostenki on both of these maps) and further in the northeast - circumpolar Mamontova kurya (yellow dot only in Fig. 2) (L, 2021).

The longest, most interesting and most fully recorded with the aid of archaeological excavations turned out to be the path from Kostenki of southern, Grimaldian race. In a month or two, they crossed ash zone, reaching its southern border in the lower reaches of Don. Further, like all other Cro-Magnons, they 
began to move south in the standard style of permanent resettlement, but at non-standard speed, at least $2.3 \mathrm{~km}$ per year. This speed, of course, was 3 times lower than American settlers demonstrated after $\sim 20$ kyr, but also 3 times higher than that of Brünners at the same time. The first point in which the Grimaldians' campaign was traced was Mezmay cave (the yellow point in both Fig. 2 and Fig. 5, lying on the westernmost edge of Caucasian ridge, which blocked the way for the Grimaldians to the south). After bypassing the mountains from the west, they came to Black Sea/Lake, and they had the only way to the southeast along its shore (ash lay from the west). Then - Zagros Mountains and river valleys of Mesopotamia, which led them further to the southeast, and Grimaldians again left their traces in the mountain in Yafte cave (another yellow dot in Fig. 2 and also in Fig. 5). This cave was not far from the key (light green) point of first campaign of sapiens to the east, more than $80 \mathrm{kyr}$ before the events described here, - Houmian shelter. This time, Persian Gulf protruded inland much less than then, and the Grimaldians could go along the border of Iranian semi-desert and Arabian Desert to the old site of first campaign - Jebel Faya (a pair of green and yellow dots in Fig. 2 not far from Strait of Hormuz, which actually turned into a bay). It was at this time that short and strong climate fluctuations took place, and about $37 \mathrm{ka}$ BP there was one such sharp warming. Before Grimaldians, for a short time, a path was opened through the desert along Arabian coast to "Happy Arabia" and Bab-el-Mandeb Strait, which they crossed on the move. And, according to our estimate, $35.9 \mathrm{ka} \mathrm{BP}$ they entered the coast of Africa, to the place where their distant ancestors had started their campaign 94 kyr before (L, 2021).

It seems that Europeans, who lived near the glaciers, here, not very far from the equator, were too hot, and they decided to move on at the same pace. In the 3400 years since the exit from Kostenki, the number of Grimaldians should have grown, and they divided into two groups: one went north, and the other went south in search of a more suitable place to live. The first group soon stumbled upon the upper reaches of some river, the waters of which flow into Nile, and moved along it to the desired coolness (which they never found there) along the river valleys, and somewhere around $34.2 \mathrm{ka} \mathrm{BP}$, finally settled in Egypt in point Nazlet Hater (yellow dot in Fig. 2). And the second group, after almost 3 kyr, went into relatively cool South Africa, and stopped in the vicinity of Hofmeir and at least three more well dated sites - on the banks of the river in Mozambique (Txina-Txina) and in two caves (Rose Cottage and Boomplaas), see 4 yellow dots in fig. 2, the time of appearance of which is about $33.5-32.5 \mathrm{ka}$ BP. No matter how the relations of Cro-Magnons (Grimaldians) with local African archaic sapiens, according to genetic data, the result is known - practically all representatives of modern Negro race have Y-haplogroup that arose from the descendants of only a handful of people who survived after the Catastrophe in Eurasia. It is unlikely that this is due to the fact that a small amount of aliens killed all African men. The reason, apparently, is that men of a more modern type ousted in the process of sexual selection the carriers of 
ancient Y-haplogroups, which arose before sapiens left Africa $130 \mathrm{ka} \mathrm{BP}$ (L, 2021). And they turned black, as you know, already at the beginning of the Holocene, apparently after a sharp global warming (see Fig. 1) forced them to take off their outerwear and expose their skin to direct sunlight.

And to conclude this section, let's take another look at the map of Old World (Fig. 2). In the period between the catastrophic eruption of Archiflegreo stratovolcano and $30 \mathrm{ka} \mathrm{BP}$, at the fourth stage of the war, the northern sapiens restored and expanded their position in Europe (with the exception of depopulated Greece), destroyed or finally displaced Neanderthals of Zagros and Iranian Highlands, have moved further north, settled in Africa, in order to replace the vast majority of the archaic African population in the future and at the same time turn black themselves. And, finally, settling the territories of East Asia, they began to retreat from there under the pressure of easterners, who, moreover, went far north to the Arctic coast of Eurasia (Yanskaya, Orlovka and Kymyneykey sites - yellow dots with a light green center in Fig. 2), creating a springboard for conquest of America. In the Far East, they went out into Open Ocean and have swum to Okinawa Island (see the yellow dot with a light green center in Fig. 2, which is the easternmost in the Northern Hemisphere, in Fig. 2). On the Wallace Line, they finally met the southerners (yellow dots with a light green center in eastern Java (Wajak, $37.5 \mathrm{ka} \mathrm{BP}$ ), in the south of Sulawesi (Leang Burung, 37 ka BP), and brown dot on Timor ( 43 ka BP) in Fig. 2) (L, 2021).

\section{ORIGIN OF RACES AND PALEOGENETICS}

As the result of a system analysis of data related to 88 points, 3 refugees were found, in which sapiens survived after the catastrophic eruption of Toba stratovolcano, the strongest, at least in the last 2 million years. Let us also try very briefly to link these results with some anthropological and paleogenetic data.

Already more than a quarter of a century ago, in 1994, an attempt was made to objectively assess the proximity (or remoteness) of human populations using genetic variability in hypervariable loci (polymorphic microsatellites), which was previously used for individual identification and analysis of human relationships (Bowcock, A. et al., 1994). For 14 human populations, the so-called phylogenetic evolutionary tree was built, reproduced in Fig. 6: 
Fig. 6 - Phylogenetic "human evolutionary tree"

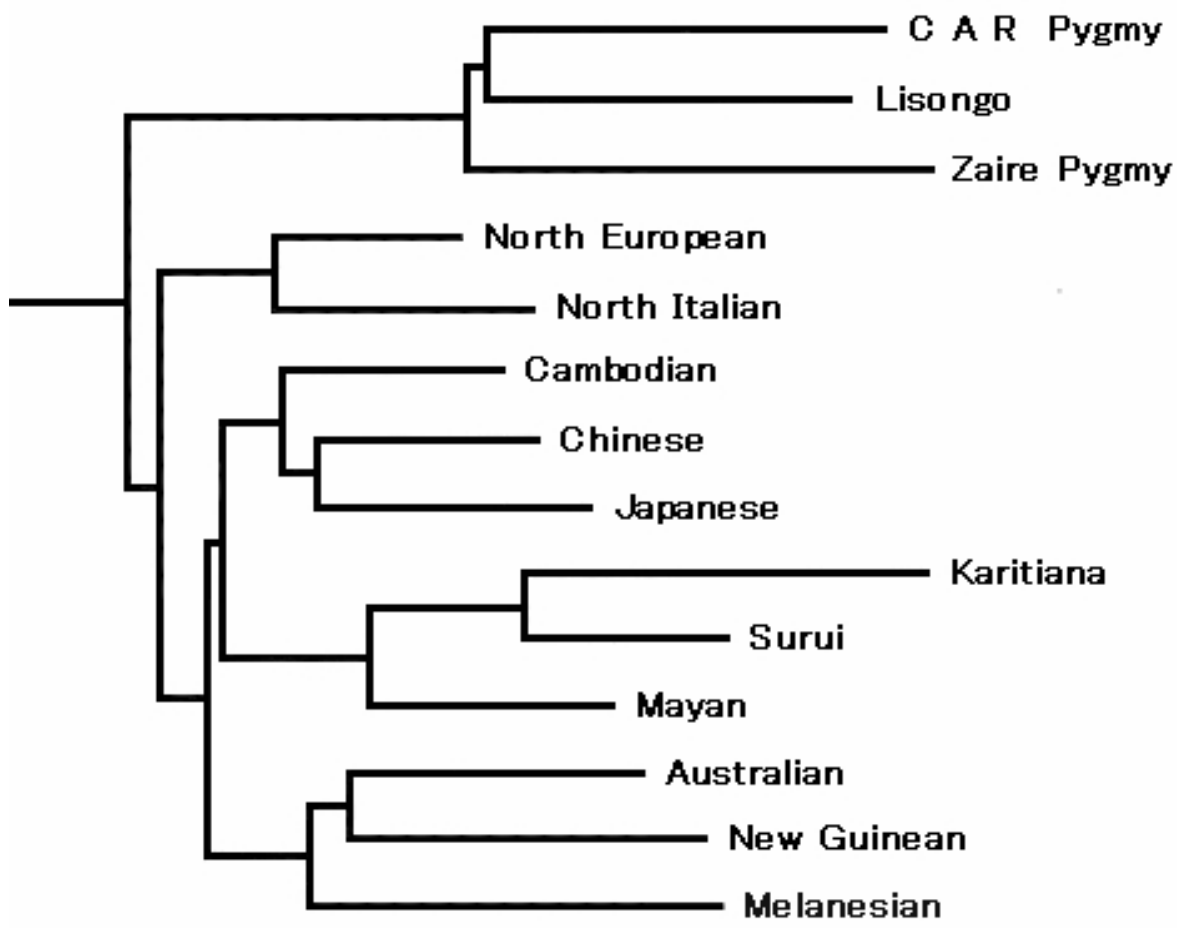

If we confront nodes (forks) of the phylogenetic tree with the spatial-temporal points of the process described in this work, then the first fork between African relicts submitted in Fig. 6 - pygmies (Pygmy, Lisongo), and the ancestors of modern people arose about $130 \mathrm{ka}$ BP after their transition to Arabia. The second fork between the ancestors of Europeoids (North European, North Italian) and all the rest - after the former remained in northern India and the latter went further east into Southeast Asia for about 96 $95 \mathrm{ka} \mathrm{BP}$. The third fork is direct evidence of the Catastrophe caused by the unprecedented eruption of Toba stratovolcano $72 \mathrm{ka} \mathrm{BP.} \mathrm{For} \mathrm{tens} \mathrm{of} \mathrm{thousands} \mathrm{of} \mathrm{years} \mathrm{after} \mathrm{it} \mathrm{(and} \mathrm{by} \mathrm{and} \mathrm{large,} \mathrm{perhaps} \mathrm{forever),}$ the development paths of easterners - the ancestors of the Asians and American Indians (from Cambodian to Mayan), and the Southerners - Australian, New Guinean and Melanesian, have diverged. The fourth fork on the phylogenetic tree, between Asians and Indians of America, goes beyond the boundaries of the time interval we are considering, but is well known to anthropologists, and it happened between $25-15$ ka BP after the opening of the land bridge between Asia and America in Beringia, and then its closure 11 ka BP. Even earlier, about 35 ka BP from the European race was separated Negro, but in Fig. 6 this fork is absent due to the fact that not a single Negro population was considered in work (Bowcock, A. et al., 1994).

So, from a systemic point of view, it should be considered that now there are five races of modern humanity, three of them (Europeoids (Caucasians), Mongoloids and Australoids) arose originally from 
three small groups of sapiens who survived after the Catastrophe in three isolated refuges, and from two of this races later two more races split off (Negro and American) also due to the geographical isolation of Africa and America. In addition, small populations of sapient relicts in Africa, on which the explosion of Toba volcano didn't have such a strong effect as on Asian sapiens, represent another, sixth (KhoisanoPygmy) human race.

It should be noted that, as far as the author knows, the first who in our time began to write that "a large amount of factual material has been accumulated, allowing us to propose a hypothesis about three large geographical zones, in which 100 - 30 thousand years the process of transition from the Middle to Upper Paleolithic took place in different ways, and to outline three scenarios (models) of this process", was famous archaeologist A. P. Derevianko (Derevianko, A. P., 2011). In the article (Derevianko, A. P., Shunkov, M. V., 2011), published immediately after the above book, it was written that it was in these three zones that "the evolution of the physical type of man took place, which ultimately led to formation of Homo sapiens sapiens". However, that concept spoke about other zones of the emergence of modern man (Africa, East Asia and Europe), about completely different processes and different times of the emergence of individual "races" (from 200 to $30 \mathrm{ka} \mathrm{BP}$ ). What kind of single "modern people" could be generally talked about with such a scatter of times, places and processes of their origin? But, nevertheless, the intuition of the most experienced archaeologist in something turned out to be completely correct.

\section{CONCLUSIONS}

This work describes the process of development over $100 \mathrm{kyr}$ of a complex system, which was a kind of community of sapiens that stood out from all of humanity that was an ensemble of several species of hominins, from the moment of its appearance until the time when it practically began to coincide with humanity as a whole. In accordance with the principles of system theory, and its most developed area system engineering, the first approximation of the description of this process is presented. Language of war and hostilities was chosen as the language of its description, because the result of this process coincided with the result of any war that ended in the most decisive way: at the beginning there were several (at least five) warring parties, and at the end - only one winner - Homo sapiens sapiens, which arose itself in its complete forms as a result of this process. It was these military campaigns, together with external influences of irresistible force - the explosions of Toba and Archiflegreo stratovolcanoes that were decisive in formation of the results of this process on the Earth by the end of $100 \mathrm{kyr}$ period after first group of sapiens left Africa that has occurred about $130 \mathrm{ka} \mathrm{BP.}$

It is shown that modern humans descended from three small groups of sapiens who survived the explosion of Toba volcano in Khatlon valley among Pamir Mountains in the north, on Timor Island in the 
south, and on Greater Luzon Island in the east. And they gave rise to three types of modern people northern, southern and eastern and three primary modern races. In addition, a small number of relicts have survived in Africa - descendants of archaic sapiens, whose ancestors split off from the phylogenetic tree of modern humans before the sapiens left Africa $130 \mathrm{ka} \mathrm{BP.}$

These results were achieved using a system approach. More 57 years ago, in 1964, well-known Soviet and Russian system methodologist G. P. Shchedrovitsky wrote about the victory of a new point of view - a systemic "vision of objects" and "a broad transition to systemic subjects and problems, which was a consequence of internal development of science" (Integrating Program Management..., 2017 2020). However, at least in the field of human sciences, he was, as time has shown, overly optimistic. Even half a century later, A. P. Derevyanko only hoped for much less, that "... the time has come for all conclusions, ideas, hypotheses expressed by scientists from different directions of Human science, if not to bring into a single system, then at least thoroughly discuss, but with one indispensable condition: they must be based on the results of research not only of their own, but also of colleagues from related sciences. This is a multidisciplinary problem, and its solution can't be limited to the conclusions of only geneticists, or anthropologists, or archaeologists. Only a respectful attitude towards the results obtained by colleagues from related sciences will one day lead us to the truth" (Derevianko, A. P., 2011). This is exactly what was done in work (L, 2021) - a multidisciplinary problem was solved by a multidisciplinary systemic method, and this solution awaits the "respectful attitude" of colleagues. 


\section{BIBLIOGRAPHIC REFERENCES}

Aleksenko, A. (2019). How Russia and United States filled in the Periodic table. Forbs, Technologies. // https://www.forbes.ru/tehnologii/371847-kak-rossiya-i-ssha-zapolnyali-tablicu-mendeleeva (in Russin) Bertalanffy, von, L. (1969). General System Theory. George Braziller, New York, Canada, 153 pp. Bowcock, A. et al. (1994). High Resolution of human evolutionary Trees with polymorphic microsatellites. Nature, 368 (6470) //

https://www.researchgate.net/publication/15687958_High_Resolution_of_human_evolutionary_Trees_ with_polymorphic_microsatellites

Haws, J. A. et al. (2020). The early Aurignacian dispersal of modern humans into westernmost Eurasia. PNAS, 117 (41). // https://www.pnas.org/content/117/41/25414

Derevianko, A. P. (2011). Upper Paleolithic in Africa and Eurasia and formation of a modern human anatomical type. Novosibirsk, Publishing House of the Institute of Archeology and Ethnography, SB RAS, 561 pp. // https://www.klex.ru/s6d (in Russian)

Derevianko, A. P., Shunkov, M. V. (2011). How many ancestors does a modern man have? In Defence of Science, N 9. // https://studylib.ru/doc/2069162/skol._ko-predkov-u-sovremennogo-cheloveka\%3F // (in Russian)

Liddell Hart, B. H. (1967). The Strategy of Indirect Approach. London, Faber, 430 pp.

Lobanovsky, Yu. I. (2021). Great War and three ancestral homelands of modern humans. Synerjetics Group, 72 pp. http://www.synerjetics.ru/article/3_ancestral_lands.pdf (in Russian) (L, 2021)

Longrich, N. (2020). The Out-of-Africa Offensive. https://www.nicklongrich.com/blog/the-out-of-africaoffensive

Peregudov, F. I., Tarasenko, F. P. (1989). Introduction to system analysis. Moscow, Higher School, 360 pp. (in Russian)

Integrating Program Management and System Engineering. (2017). E. S. Rebentisch, Editor in Chief. Wiley, 456 pp. (in Russian Appeal to Readers, 2020).

The Art of War: Sun Zi's Military Methods. (2007). Columbia University Press, 256 pp. 